\title{
Touchdown General Primer (GP5+/GP6+) PCR and optimized sample DNA concentration support the sensitive detection of human papillomavirus
}

\author{
Mark F Evans*, Christine SC Adamson, Linda Simmons-Arnold and \\ Kumarasen Cooper
}

Address: Department of Pathology, University of Vermont, Burlington, Vermont 05405, USA

Email: Mark F Evans* - mark.evans@uvm.edu; Christine SC Adamson - christine.adamson@uvm.edu; Linda Simmons-Arnold - linda.simmonsarnold@uvm.edu; Kumarasen Cooper - kum.cooper@vtmednet.org

* Corresponding author

Published: 16 November 2005

BMC Clinical Pathology 2005, 5:10 doi:10.1 186/1472-6890-5-10

This article is available from: http://www.biomedcentral.com/1472-6890/5/10

(c) 2005 Evans et al; licensee BioMed Central Ltd.

This is an Open Access article distributed under the terms of the Creative Commons Attribution License (http://creativecommons.org/licenses/by/2.0), which permits unrestricted use, distribution, and reproduction in any medium, provided the original work is properly cited.
Received: 23 June 2005

Accepted: 16 November 2005

\begin{abstract}
Background: The GP5+/GP6+ PCR assay is a well-established HPV detection technique. This study has examined the effects of incorporating 'hot start' and 'touchdown' steps into the protocol. In addition, dTTP was substituted with dUTP to permit contamination control measures against carry-over PCR product.
\end{abstract}

Methods: Firstly, HPV-I6 was amplified from SiHa cell DNA (0.I ng-100 ng) diluted in a background of C-33A DNA (I00 ng$2 \mu \mathrm{g}$ ). Secondly, the detection of small quantities (I5ag-I.5pg) of HPV recombinant plasmids (types I6, 3I, 33, 45, 5I, 52, and 56) diluted in C-33A DNA was investigated. Thirdly, clinical sample DNA extracts (cervical smears, formalin-fixed vaginal lesions and breast tumors) were tested for HPV. Six different PCR protocols were assessed. HPV was detected by gel electrophoresis, and by Southern and dot blot hybridization.

Results: HPV detection sensitivity was dependent on the total amount of DNA in a PCR. Touchdown protocols supported HPV-I 6 detection from I ng or $0.5 \mathrm{ng}$ SiHa cell DNA in a background of $2 \mu \mathrm{g}$ or I $\mu \mathrm{g}$ C-33A DNA respectively, and from 0.1 $\mathrm{ng}$ of $\mathrm{SiHa}$ cell DNA ( 28 copies HPV-16) in $500 \mathrm{ng}$ or $100 \mathrm{ng}$ background DNA. Under standard GP5+/GP6+ annealing conditions, HPV-I6 went undetected when the DNA content of a PCR was $2 \mu \mathrm{g}$ or I $\mu \mathrm{g}$, and with 500 ng C-33A DNA the sensitivity limit was I ng SiHa cell DNA. HPV recombinant plasmids were each detected with high (albeit varying) sensitivity by a touchdown protocol. HPV-3 I was better amplified under standard annealing conditions (I.5fg in I00 ng background DNA) than by a touchdown approach (I $5 \mathrm{fg}$ detection limit). HPV-52 was not amplified by the standard protocol at the dilutions tested. Seventeen different HPV types were demonstrated in $47 / 65$ (72\%) abnormal cytology samples recorded as HPV negative by standard GP5+/GP6+ conditions. Twenty-one different HPV types were recorded in III/II4 (97\%) vaginal lesions. Multiple infections were also detectable using a touchdown approach. Of 26 breast tumors, 5 (I9\%) tested HPV positive by the standard assay and I5/26 (58\%) using a touchdown protocol.

Conclusion: Touchdown modification of the GP5+/GP6+ PCR assay enables the detection of HPV undetected under regular assay conditions. The use of standardized DNA quantities in a PCR rather than standard sample volumes containing arbitrary amounts of DNA is supported. A touchdown approach may be beneficial as an analytical test for the re-evaluation of (apparently) HPV negative abnormal cervical cytological or histological samples, and for investigating the association of HPV with disease conditions at diverse organ sites. The clinical utility of a touchdown approach for HPV detection requires further investigation as increased assay analytical sensitivity may not necessarily equate with improved clinical sensitivity or specificity. 


\section{Background}

The association of human papillomaviruses (HPV) with invasive cervical carcinoma and its precursor lesions is well characterized $[1,2]$. There is also an emerging body of data indicating that HPV may contribute to tumor etiology at a variety of other anatomical sites [3]. For example, high-risk HPV types have been detected in up to $48 \%$ of breast carcinomas [4], although other studies have reported an absence of HPV in these tumors [5].

Clearly, any estimate of HPV prevalence amongst a tissue sample set is dependent on the detection method used. Commonly employed PCR based assays include the General Primer Mediated 5+/6+ (GP5+/GP6+) [6,7] and the MY09/MY11 [8] systems that amplify sequences from the $L 1$ region of the HPV genome. Since the early/mid-90 s, when these assays were first developed a number of modifications that can improve PCR efficiency have been described. In addition, there have been improvements in thermal cycler specifications. This study has examined the effects of incorporating 'hot start' [9] and 'touchdown' [10] steps into the GP5+/GP6+ assay. Assays have been tested for use with dUTP instead of dTTP so that a uracil $\mathrm{N}$-glycosylase (UNG) pre-PCR-incubation step can be included to degrade any contaminating carry-over PCR product present at reaction set up. The effect of the quantity of background DNA in an individual PCR on the limits of HPV detection has been specially investigated. Protocols have been tested on HPV recombinant plasmids, and DNA extracted from cervical cell lines, cervical cytology samples, and from formalin-fixed, paraffinembedded (FFPE) vaginal intraepithelial neoplasia (VAIN) lesions and breast invasive ductal carcinomas (IDC).

\section{Methods}

\section{Materials}

All patient materials used in this study were obtained and analyzed with Institutional Review Board approval.

\section{Cell lines}

SiHa cells that contain one copy of the HPV-16 genome integrated at chromosome 13q21-31 [11], and C-33A cells derived from an HPV negative cervical carcinoma, were acquired from the American Tissue Culture Collection (ATCC), Manassas, VA.

\section{HPV recombinant plasmids}

HPV types 16, 45, and 51 were received courtesy of Dr. E$M$ de Villiers, Deutsches Krebsforschungszentrum (dkfz), Heidelberg, Germany. HPV-33 was received courtesy of Dr. Gerard Orth, Institut Pasteur, Paris, France. HPV-31, 52 , and 56 were obtained from the ATCC.

\section{Cervical cytology samples}

Remnant cells (following cervical smear testing) were obtained from samples diagnosed as low-grade cervical squamous intraepithelial lesion (LSIL), abnormal squamous cells of undetermined significance (ASC-US), abnormal squamous cells cannot exclude HSIL (ASC-H), or, high-grade squamous intraepithelial lesion (HSIL).

Breast invasive ductal carcinomas

Twenty-six FFPE IDC samples were selected at random from Fletcher Allen Health Care Pathology (FAHC) archives.

\section{Vaginal intraepithelial neoplasia samples}

114 FFPE VAIN samples were retrieved from FAHC archives.

\section{DNA extraction and quantification}

DNA was extracted and purified from cultured SiHa and C-33A cells and from cytology samples by proteinase $\mathrm{K}$ digestion followed with a column clean-up method (Qiagen DNeasy Tissue Kit). DNA was extracted from FFPE tissues by digesting five $6 \mu \mathrm{m}$ dewaxed sections with proteinase K as previously described [12]. DNA concentrations were estimated using a DyNA Quant 200 Fluorometer (Hoeffer Scientific).

Table I: Details of the PCR protocols tested. All protocols included substitution of dTTP with dUTP and commenced with a uracil Nglycosylase (UNG) incubation step $\left(37^{\circ} \mathrm{C}\right.$ for 30 minutes) followed by a HotStarTaq DNA Polymerase (Qiagen) activation/UNG inactivation step $\left(95^{\circ} \mathrm{C}, 15 \mathrm{~min}\right)$.

\begin{tabular}{|c|c|c|c|c|c|}
\hline Protocol & Denaturation & Touchdown annealing cycles & Additional annealing cycles & Extension & Final extension \\
\hline GP5+/GP6+ & $1 \min , 94^{\circ} \mathrm{C}$ & - & $2 \mathrm{~min}, 40^{\circ} \mathrm{C}(40-50$ cycles $)$ & $1.5 \min , 72^{\circ} \mathrm{C}$ & $4 \min , 72^{\circ} \mathrm{C}$ \\
\hline TDPI & $1 \mathrm{~min}, 94^{\circ} \mathrm{C}$ & $\begin{array}{c}2 \mathrm{~min}, 45^{\circ} \mathrm{C} \text { to } 40^{\circ} \mathrm{C} \text { in } 0.5^{\circ} \mathrm{C} \\
\text { decrements ( } 11 \text { cycles) }\end{array}$ & $2 \mathrm{~min}, 40^{\circ} \mathrm{C}$ ( $29-39$ cycles $)$ & $1.5 \min , 72^{\circ} \mathrm{C}$ & $4 \min , 72^{\circ} \mathrm{C}$ \\
\hline TDP2 & $1 \mathrm{~min}, 94^{\circ} \mathrm{C}$ & $\begin{array}{c}2 \mathrm{~min}, 50^{\circ} \mathrm{C} \text { to } 40^{\circ} \mathrm{C} \text { in } 1.0^{\circ} \mathrm{C} \\
\text { decrements ( } 11 \text { cycles })\end{array}$ & $2 \mathrm{~min}, 40^{\circ} \mathrm{C}$ ( $29-39$ cycles) & $1.5 \mathrm{~min}, 72^{\circ} \mathrm{C}$ & $4 \mathrm{~min}, 72^{\circ} \mathrm{C}$ \\
\hline TDP3 & $1 \min , 94^{\circ} \mathrm{C}$ & $\begin{array}{c}2 \mathrm{~min}, 50^{\circ} \mathrm{C} \text { to } 40^{\circ} \mathrm{C} \text { in } 0.5^{\circ} \mathrm{C} \\
\text { decrements }(21 \text { cycles })\end{array}$ & $2 \mathrm{~min}, 40^{\circ} \mathrm{C}$ (19-29 cycles) & $1.5 \min , 72^{\circ} \mathrm{C}$ & $4 \mathrm{~min}, 72^{\circ} \mathrm{C}$ \\
\hline TDP4 & $1 \min , 94^{\circ} \mathrm{C}$ & $\begin{array}{c}2 \mathrm{~min}, 55^{\circ} \mathrm{C} \text { to } 40^{\circ} \mathrm{C} \text { in } 1.0^{\circ} \mathrm{C} \\
\text { decrements }(16 \text { cycles })\end{array}$ & $2 \min , 40^{\circ} \mathrm{C}$ ( $24-34$ cycles $)$ & $1.5 \min , 72^{\circ} \mathrm{C}$ & $4 \mathrm{~min}, 72^{\circ} \mathrm{C}$ \\
\hline
\end{tabular}


Table 2: PCR protocol sensitivities for the detection of HPV-16 in SiHa/C-33A DNA mixtures. SiHa cell DNA (0.I ng to I00 ng) was mixed with C-33A cell DNA to give final DNA quantities of $2 \mu \mathrm{g}, I \mu \mathrm{g}, 0.5 \mu \mathrm{g}$, or $0.1 \mu \mathrm{g}$. These preparations were tested with up to six different PCR protocols. HPV-16 detection was most successful using by the TDP3 and TDP4 conditions. Data are for protocols tested at 50 PCR cycles. ${ }^{\checkmark}$ HPV detected, ${ }^{x}$ HPV undetected, ND: not done.

\begin{tabular}{|c|c|c|c|c|c|c|c|c|c|c|}
\hline \multirow[b]{2}{*}{ SiHa DNA } & \multicolumn{5}{|c|}{ Total DNA in PCR: $2 \mu \mathrm{g}$} & \multicolumn{5}{|c|}{ Total DNA in PCR: I $\mu \mathrm{g}$} \\
\hline & $100 \mathrm{ng}$ & $25 \mathrm{ng}$ & I ng & $0.5 \mathrm{ng}$ & $0.1 \mathrm{ng}$ & $100 \mathrm{ng}$ & $25 \mathrm{ng}$ & I ng & $0.5 \mathrm{ng}$ & $0.1 \mathrm{ng}$ \\
\hline GP5+/6+ & $x$ & $x$ & $x$ & $x$ & $x$ & $x$ & $x$ & $x$ & $x$ & $x$ \\
\hline TDPI & $x$ & $x$ & $x$ & $x$ & $x$ & $\checkmark$ & $\checkmark$ & $x$ & $x$ & $x$ \\
\hline TDP2 & $\checkmark$ & $\checkmark$ & $x$ & $x$ & $x$ & $\checkmark$ & $\checkmark$ & $\checkmark$ & $x$ & $x$ \\
\hline TDP3 & $\checkmark$ & $\checkmark$ & $\checkmark$ & $x$ & $x$ & $\checkmark$ & $\checkmark$ & $\checkmark$ & $\checkmark$ & $x$ \\
\hline TDP4 & ND & ND & ND & ND & ND & $\checkmark$ & $\checkmark$ & $\checkmark$ & $\checkmark$ & $x$ \\
\hline \multirow[t]{2}{*}{ MRT } & ND & ND & ND & ND & ND & ND & ND & ND & ND & ND \\
\hline & \multicolumn{5}{|c|}{ Total DNA in PCR: $0.5 \mu \mathrm{g}$} & \multicolumn{5}{|c|}{ Total DNA in PCR: $0.1 \mu \mathrm{g}$} \\
\hline SiHa DNA & $100 \mathrm{ng}$ & $25 \mathrm{ng}$ & I ng & $0.5 \mathrm{ng}$ & $0.1 \mathrm{ng}$ & $100 \mathrm{ng}$ & $25 \mathrm{ng}$ & I ng & $0.5 \mathrm{ng}$ & $0.1 \mathrm{ng}$ \\
\hline GP5+16+ & $\checkmark$ & $\checkmark$ & $\checkmark$ & $x$ & $x$ & $\checkmark$ & $\checkmark$ & $x$ & $x$ & $x$ \\
\hline TDPI & $\checkmark$ & $\checkmark$ & $\checkmark$ & $\checkmark$ & $x$ & $\checkmark$ & $\checkmark$ & $\checkmark$ & $x$ & $x$ \\
\hline TDP2 & $\checkmark$ & $\checkmark$ & $\checkmark$ & $\checkmark$ & $\checkmark$ & $\checkmark$ & $\checkmark$ & $\checkmark$ & $\checkmark$ & $x$ \\
\hline TDP3 & $\checkmark$ & $\checkmark$ & $\checkmark$ & $\checkmark$ & $\checkmark$ & $\checkmark$ & $\checkmark$ & $\checkmark$ & $\checkmark$ & $\checkmark$ \\
\hline TDP4 & $\checkmark$ & $\checkmark$ & $\checkmark$ & $\checkmark$ & $\checkmark$ & $\checkmark$ & $\checkmark$ & $\checkmark$ & $\checkmark$ & $\checkmark$ \\
\hline MRT & ND & ND & ND & ND & ND & $\checkmark$ & $\checkmark$ & $\checkmark$ & $\checkmark$ & $\checkmark$ \\
\hline
\end{tabular}

\section{PCR protocols}

The PCR protocols tested are summarized in Table 1. Initially, the standard GP5+/GP6+ assay cycling conditions and four different touchdown protocols were compared. In all protocols dTTP was substituted with dUTP (ACGU dNTP mix [Sigma A5593]) and included a pre-PCR incubation step with 'heat-killed'-Uracil N-Glycosylase ( $\mathrm{HK}^{\mathrm{TM}}$ UNG, Epicentre). $\mathrm{HK}^{\mathrm{TM}}$-UNG is a heat-labile form of UNG that has maximal activity at $50^{\circ} \mathrm{C}$ and is designed to be completely inactivated by 10 minute incubation at $65^{\circ} \mathrm{C}$ (Epicentre technical note). Samples were incubated at $37^{\circ} \mathrm{C}$ for $30 \mathrm{~min}$ with $0.2 \mathrm{U} \mathrm{HK}^{\mathrm{TM}}$-UNG according to supplier's recommendations. A 'hot-start' step followed utilizing HotStarTaq DNA Polymerase (Qiagen), which requires incubation at $95^{\circ} \mathrm{C}$ for $15 \mathrm{~min}$ to activate the Taq. HotStarTaq was used at a concentration of $1 U$ per 50 $\mu l$ reaction. Magnesium chloride was included in reactions at a concentration of $4 \mathrm{mM}$. Other reaction conditions held constant for each protocol included $1 \mathrm{X}$ HotStarTaq buffer [Tris-HCl (pH8.7), $\mathrm{KCl},\left(\mathrm{NH}_{4}\right)_{2} \mathrm{SO}_{4}$ ], and each primer at a concentration of $1 \mu \mathrm{M},\left(\mathrm{GP} 5+\left[5^{\prime}-\right.\right.$ TTTGTTACTGTGGTAGATACTAC-3'] and GP6+ [5'GAAAAATAAACTGTAAATCATATTC-3']). The $\mathrm{T}_{\mathrm{m}}$ of the $\mathrm{GP} 5+$ primer is $45^{\circ} \mathrm{C}$ and the $\mathrm{T}_{\mathrm{m}}$ of the $\mathrm{GP} 6+$ primer is $41^{\circ} \mathrm{C},\left(\mathrm{T}_{\mathrm{m}}\right.$ values are estimated for $50 \mathrm{mM}$ salt conditions and are calculated from the equation $\mathrm{T}_{\mathrm{m}}=59.9+41$ [\%GC] - [675/Primer Length]).

The standard GP5+/GP6+ amplification cycles comprise 1 $\min$ at $94^{\circ} \mathrm{C}, 2 \mathrm{~min}$ at $40^{\circ} \mathrm{C}$, and $1.5 \mathrm{~min}$ at $72^{\circ} \mathrm{C}$, with the final extension step prolonged to $4 \mathrm{~min}$ to ensure complete amplification of the $140-150$ base pair products $[6,7]$. The standard denaturation and extension temperatures and times were retained in the four 'touchdown' protocols tested. The annealing period of $2 \mathrm{~min}$ was also retained, as was the 'final' annealing temperature of $40^{\circ} \mathrm{C}$. Touchdown protocols (Table 1 ) with starting annealing temperatures of $45^{\circ} \mathrm{C}, 50^{\circ} \mathrm{C}$, or $55^{\circ} \mathrm{C}$, decreasing by $0.5^{\circ} \mathrm{C}$ or $1.0^{\circ} \mathrm{C}$ decrements per PCR cycle down to $40^{\circ} \mathrm{C}$ were evaluated. All PCR protocols were tried at 40 up to 


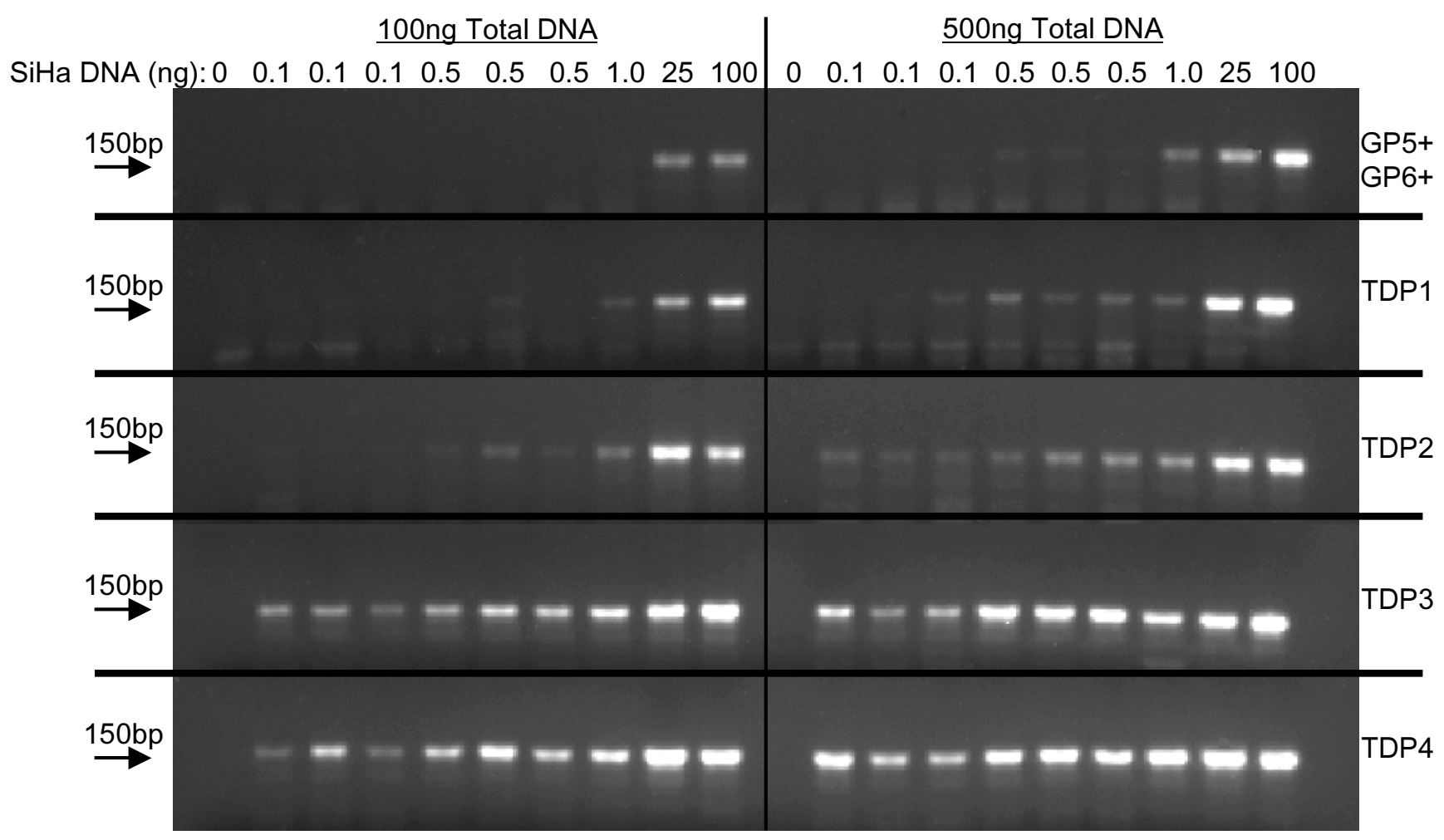

Figure I

Detection of HPV-I 6 PCR product by agarose gel electrophoresis. SiHa cell DNA, 0, 0.I, 0.5, I.0, 25, or I00 ng, was diluted in C-33A DNA to give a total of $0.5 \mu \mathrm{g}$ or $0.1 \mu \mathrm{g}$ DNA. The GP5+/GP6+, TDPI, TDP2, TDP3 and TDP4 assays were compared for the detection of HPV-16 product on an ethidium bromide $(0.5 \mu \mathrm{g} / \mathrm{ml})$ stained $2.5 \%$ agarose gel. RB: reagent blank, M: 50 base pair molecular weight ladder.

50 cycles of amplification. Protocols were variously tested with $5 \mathrm{ng}$ up to $2 \mu \mathrm{g}$ of DNA per $50 \mu \mathrm{l}$ reaction. Experiments were conducted using $0.2 \mathrm{ml}$ PCR tubes (lightly coated with mineral oil to enhance heat conduction) and a Programmable Thermal Controller-100 ${ }^{\mathrm{TM}}$ [PTC-100] (MJ Research, Inc. MA).

Following completion of the study the authors became aware of a GP5+/GP6+ protocol incorporating modified ramping times (MRT) [13]. The MRT GP5+/GP6+ conditions were tested on a subset of the samples. For the purposes of this study, the protocol was modified to include hot-start, dUTP, and 50 PCR cycles. Reaction ingredients were as above. The MRT GP5+/GP6+ cycling conditions were as follows:

HK ${ }^{\mathrm{TM}}-\mathrm{UNG}$ incubation step: $37^{\circ} \mathrm{C} 30$ mins

Denaturation/HotStarTaq activation: $95^{\circ} \mathrm{C} 15 \mathrm{mins}$

Cycles $(\mathrm{n}=50) 20 \mathrm{~s}$ at $94^{\circ} \mathrm{C}$
In $24 \mathrm{~s}$ to $90^{\circ} \mathrm{C}$

In $66 \mathrm{~s}$ to $48^{\circ} \mathrm{C}$

In $30 \mathrm{~s}$ to $38^{\circ} \mathrm{C}$

$30 \mathrm{~s}$ at $38^{\circ} \mathrm{C}$

In $18 \mathrm{~s}$ to $42^{\circ} \mathrm{C}$

In $42 \mathrm{~s}$ to $71^{\circ} \mathrm{C}$

$80 \mathrm{~s}$ at $71^{\circ} \mathrm{C}$

In $24 \mathrm{~s}$ to $69^{\circ} \mathrm{C}$

In $90 \mathrm{~s}$ to $94^{\circ} \mathrm{C}$

Final step: $4 \mathrm{~min}$ at $71^{\circ} \mathrm{C}$ 


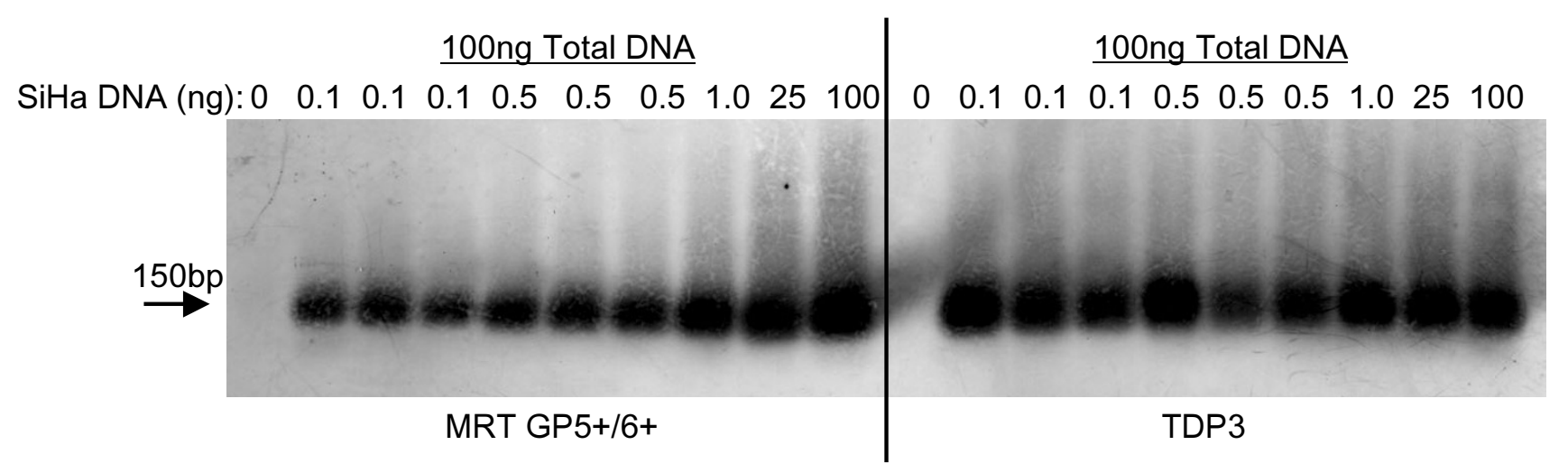

Figure 2

Southern blot of TDP3 and MRT GP5+/GP6+ PCR products. SiHa cell DNA, 0, 0.1, 0.5, I.0, 25, or I00 ng, was diluted into a total of $0.1 \mu \mathrm{g}$ DNA made up with C-33A DNA. After PCR with the TDP3 and MRT protocols and gel electrophoresis, products were electroblotted onto nylon membrane and hybridized with biotin-labeled HPV-I6 oligonucleotide probe detected with streptavidin-alkaline phosphatase and NBT/BCIP. The data confirm the $\sim 150$ bp amplicons represent HPV sequences.

\section{Control measures}

\section{$P C R$}

Negative control PCR was performed using C-33A cells and reactions containing no template DNA. PCR amplification of $\beta$-globin sequences was performed to confirm sample fitness for PCR assay [14].

FFPE tissue-block sectioning

Measures to prevent potential cross-contamination of tissue during sample sectioning, included wiping the micro- tome blade with histoclear (xylene substitute) and 'DNA-

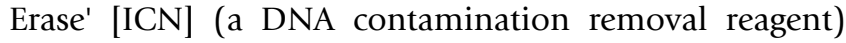
between blocks. Additionally, the first 10-20 sections cut from a specimen were discarded prior to collecting sections for DNA extraction from the specimen.

\section{HPV detection}

Protocol sensitivity was measured by the presence of a $\sim 150$ base-pair band after $10 \mu$ l PCR product had been sieved through a $2.5 \%$ agarose gel stained with $0.5 \mu \mathrm{g} / \mathrm{ml}$

Table 3: PCR sensitivities for the detection of seven different HPV types. HPV recombinant plasmids were diluted in a background of $100 \mathrm{ng}$ C-33A DNA and amplified (50 cycles) by the GP5+/GP6+ protocol or by the TDP3 method. ${ }^{\checkmark}$ HPV detected, ${ }^{x}$ HPV undetected, $\Sigma m$ Total number of mismatches between the GP5+/GP6+ primers and the target HPV type.

\begin{tabular}{|c|c|c|c|c|c|c|c|c|c|c|c|c|c|}
\hline \multirow[b]{2}{*}{$\Sigma \mathbf{m}$} & \multirow[b]{2}{*}{ HPV } & \multicolumn{6}{|c|}{ GP5+/GP6+ } & \multicolumn{6}{|c|}{ TDP3 } \\
\hline & & $1.5 \mathrm{pg}$ & $150 \mathrm{fg}$ & $15 f g$ & $\mathrm{I.5fg}$ & I50ag & $15 \mathrm{ag}$ & $1.5 p g$ & $150 \mathrm{fg}$ & $15 f g$ & $1.5 \mathrm{fg}$ & I50ag & $15 \mathrm{ag}$ \\
\hline 2 & 16 & $\checkmark$ & $\checkmark$ & $\checkmark$ & $\checkmark$ & $\checkmark$ & $x$ & $\checkmark$ & $\checkmark$ & $\checkmark$ & $\checkmark$ & $\checkmark$ & $\checkmark$ \\
\hline 3 & 33 & $\checkmark$ & $\checkmark$ & $x$ & $x$ & $x$ & $x$ & $\checkmark$ & $\checkmark$ & $\checkmark$ & $x$ & $x$ & $x$ \\
\hline 3 & 45 & $\checkmark$ & $\checkmark$ & $\checkmark$ & $\checkmark$ & $x$ & $x$ & $\checkmark$ & $\checkmark$ & $\checkmark$ & $\checkmark$ & $\checkmark$ & $\checkmark$ \\
\hline 4 & 31 & $\checkmark$ & $\checkmark$ & $\checkmark$ & $x$ & $x$ & $x$ & $\checkmark$ & $\checkmark$ & $x$ & $x$ & $x$ & $x$ \\
\hline 4 & 56 & $\checkmark$ & $\checkmark$ & $x$ & $x$ & $x$ & $x$ & $\checkmark$ & $\checkmark$ & $\checkmark$ & $x$ & $x$ & $x$ \\
\hline 7 & 52 & $x$ & $x$ & $x$ & $x$ & $x$ & $x$ & $\checkmark$ & $\checkmark$ & $\checkmark$ & $x$ & $x$ & $x$ \\
\hline 10 & 51 & $\checkmark$ & $\checkmark$ & $x$ & $x$ & $x$ & $x$ & $\checkmark$ & $\checkmark$ & $\checkmark$ & $\checkmark$ & $\checkmark$ & $x$ \\
\hline
\end{tabular}




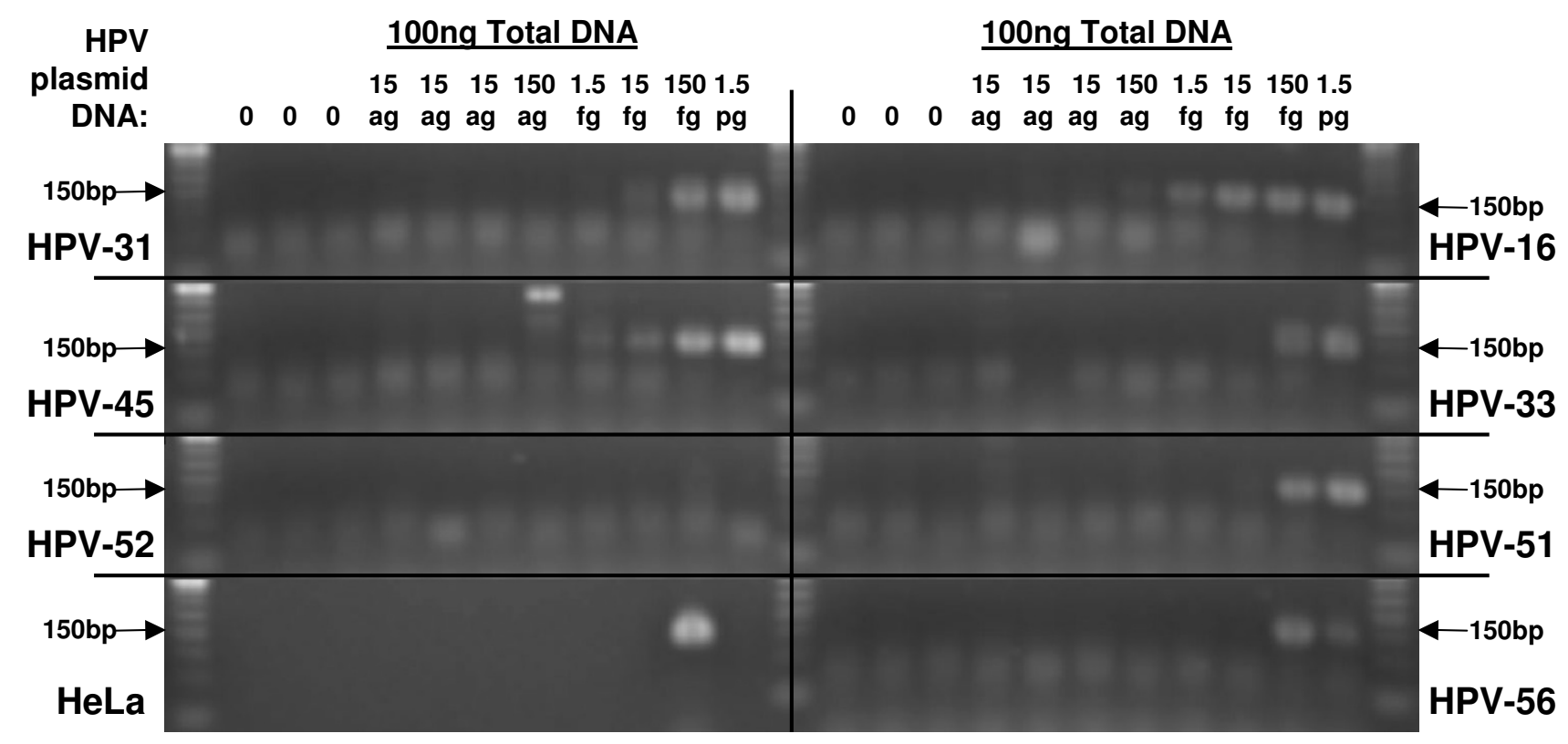

Figure 3

Detection of recombinant HPV plasmid by GP5+/GP6+ PCR. HPV (types I6, 3I, 33, 45, 5I, 52, and 56) recombinant plasmids, 0, I5ag, I50ag, I.5fg, I5fg, I50fg, I.5pg, were diluted in $100 \mathrm{ng}$ C-33A DNA and amplified (50 cycles) using the GP5+/ GP6+ protocol. Positive control amplification of HPV-I8 from $100 \mathrm{ng}$ HeLa cell DNA is also shown.

ethidium bromide. Southern blot hybridization was performed to test that the 150 base-pair PCR product represented HPV DNA. HPV typing was performed by dot blot hybridization of PCR products with up to 37 type-specific biotin-labeled oligonucleotide probes. Biotin was detected with streptavidin-alkaline phosphatase conjugate and the substrate nitrobluetetrazolium/5-bromo-4chloro-3-indolyl phosphate [12], or by sequencing.

\section{Protocol reliability}

Touchdown protocols were assessed on two or more occasions on SiHa cell/C-33A DNA dilutions, and the TDP3 was also tested several times on recombinant HPV plasmid samples to determine data reproducibility. Clinical samples (cytology, FFPE VAIN and breast tumors) were tested once only with PCR protocols. Inter-laboratory tests of different PCR assays were not performed.

\section{Results}

\section{Detection of HPV in SiHa cells}

The ability of the protocols to amplify HPV-16 from 100 $\mathrm{ng}, 25 \mathrm{ng}$, $1 \mathrm{ng}, 0.5 \mathrm{ng}$ or $0.1 \mathrm{ng}$ of SiHa cell DNA 'hidden' in a total quantity of either $2 \mu \mathrm{g}, 1 \mu \mathrm{g}, 500 \mathrm{ng}$ or $100 \mathrm{ng}$ DNA (made up with C-33A DNA) was examined. The results are summarized in Table 2, and Figure 1. Each touchdown protocol improved the detection of HPV sequences. The best protocols were the TDP3 and TDP4 that demonstrated HPV-16 amplification from $0.1 \mathrm{ng}$ of
$\mathrm{SiHa}$ cell DNA in a total DNA content of $100 \mathrm{ng}$ or $500 \mathrm{ng}$ (Figure 1). When the total DNA content was $1 \mu \mathrm{g}$, these protocols enabled successful HPV-16 amplification from $0.5 \mathrm{ng}$ of SiHa DNA (Table 2). HPV-16 was amplifiable by the TDP3 protocol from $1 \mathrm{ng}$ of SiHa cell DNA when the total reaction DNA was $2 \mu \mathrm{g}$ (Table 2 ). The least successful protocol was the standard GP5+/GP6+ that did not amplify HPV-16 from SiHa cell DNA diluted in $1 \mu \mathrm{g}$ or 2 $\mu \mathrm{g}$ of background DNA and was only able to demonstrate HPV-16 from $1 \mathrm{ng}$ of SiHa cell DNA contained in a total of $500 \mathrm{ng}$ DNA (Table 2, Figure 1). Data was confirmed by repeat PCR tests. The MRT GP5+/GP6+ protocol was also tested on SiHa cell DNA diluted in a background of 100 ng C-33A DNA and supported detection of HPV-16 from $0.1 \mathrm{ng}$ SiHa cell DNA. Figure 2 details a Southern blot of PCR products from the TDP3 and MRT protocols hybridized with a biotin-labeled HPV-16 oligonucleotide probe.

\section{Detection of HPV recombinant plasmid DNA}

The ability of the standard GP5+/GP6+ and TDP3 protocols (50 cycles each) to amplify $15 \mathrm{ag}, 150 \mathrm{ag}, 1.5 \mathrm{fg}, 15 \mathrm{fg}$, $150 \mathrm{fg}$, or 1.5pg of HPV-16, 31, 33, 45, 51, 52, or, 56 plasmid in a background of C-33A cell DNA (to a total of 100 ng DNA per PCR) was examined. The same set of 'master dilutions' were used in the two different PCR assays. The results are shown in Figures 3 and 4, and Table 3. With the TDP3 protocol HPV-16 amplification product was observed from (all three) 15 ag recombinant plasmid dilu- 


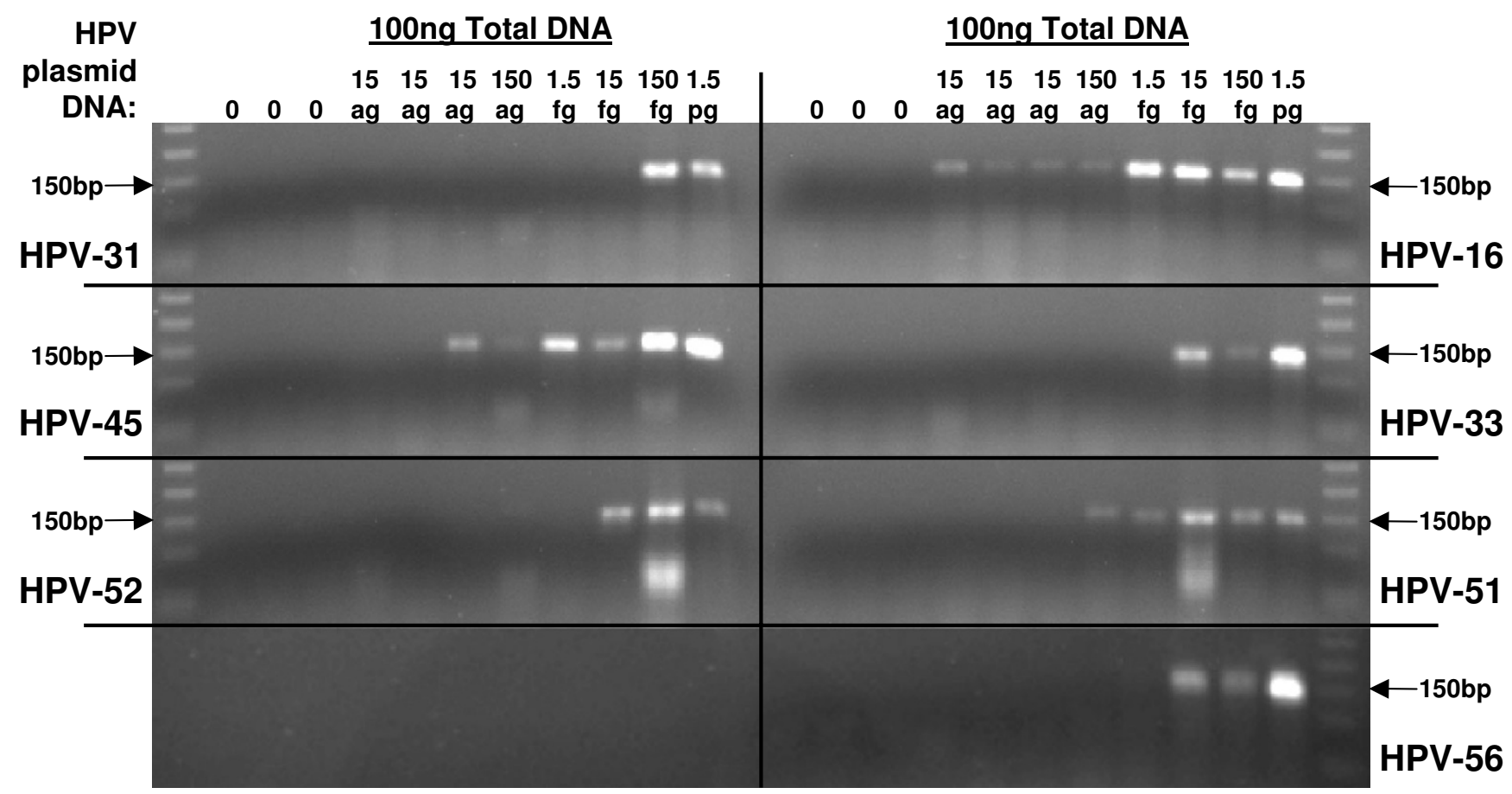

\section{Figure 4}

Detection of recombinant HPV plasmid by TDP3 PCR. HPV (types I6, 3I, 33, 45, 5I, 52, and 56) recombinant plasmids, 0, I5ag, I50ag, I.5fg, I ffg, I50fg, I.5pg, were diluted in $100 \mathrm{ng}$ C-33A DNA and amplified (50 cycles) using the TDP3 conditions.

tions, and HPV-45 from one of three 15ag HPV DNA dilutions. HPV-51 was detectable following amplification from 150ag DNA template; HPV-33, 52, and 56 from $15 \mathrm{fg}$ template; and, HPV-31 from 150 fg recombinant HPV DNA. With the GP5+/GP6+ protocol HPV-16 was amplifiable from 150ag recombinant plasmid; HPV-45 from 1.5 g template; HPV-31 from 15fg; and HPV-33, 51, and 56 from 150 fg template; HPV-52 was not detected. Data were confirmed up on repeat PCR.

\section{Detection of multiple HPV types}

To examine how a touchdown protocol affected the detection of multiple HPV types, dilutions of HPV-16, 45, 51, and 52 were combined in a background of $100 \mathrm{ng} \mathrm{C-33A}$ DNA. Five mixtures were compared: $1.5 p g$ each HPV type combined in a PCR, $150 \mathrm{fg}$ of each type in a PCR, $15 \mathrm{fg}$ of each type in a PCR, $1.5 \mathrm{fg}$ of each type in a PCR, or 150ag of each type in a PCR. Following amplification using the TDP3 protocol, duplicate rows of $0.6 \mu$ heat-denatured product was dot-blot hybridized with type-specific probes. The results are shown in Figure 5. HPV-16 was detectable following amplification of each dilution mix- ture. HPV types 45, 51, and 52 were detectable following amplification of mixtures containing $1.5 \mathrm{pg}, 150 \mathrm{fg}, 15 \mathrm{fg}$, or $1.5 \mathrm{fg}$, but not $150 \mathrm{ag}$ HPV DNA. Repeat PCR tests were not performed.

\section{Detection of HPV in cytology samples}

In a previous study [15], GP5+/GP6+ PCR was used to determine HPV type and prevalence amongst a set of abnormal cytology samples and 290/355 (82\%) were recorded as HPV positive. The TDP3 and TDP4 protocols were tested on $100 \mathrm{ng}$ and $500 \mathrm{ng}$ of DNA from samples that had tested HPV negative. Both protocols detected HPV in samples previously recorded as HPV negative, with the TDP3 representing a more efficient assay (Figure $6)$. In some instances, HPV sequences were only detectable when $100 \mathrm{ng}$ of DNA was included in the PCR, and samples were apparently HPV negative when $1.0 \mu \mathrm{g}$ or $500 \mathrm{ng}$ of sample DNA was used in an assay (Figure 7). All 65 abnormal cytology samples previously recorded as HPV negative were repeated with 50 cycles of the TDP3 protocol using $100 \mathrm{ng}$ of sample DNA as template and 47 (72\%) samples were recorded as HPV positive. Seventeen 


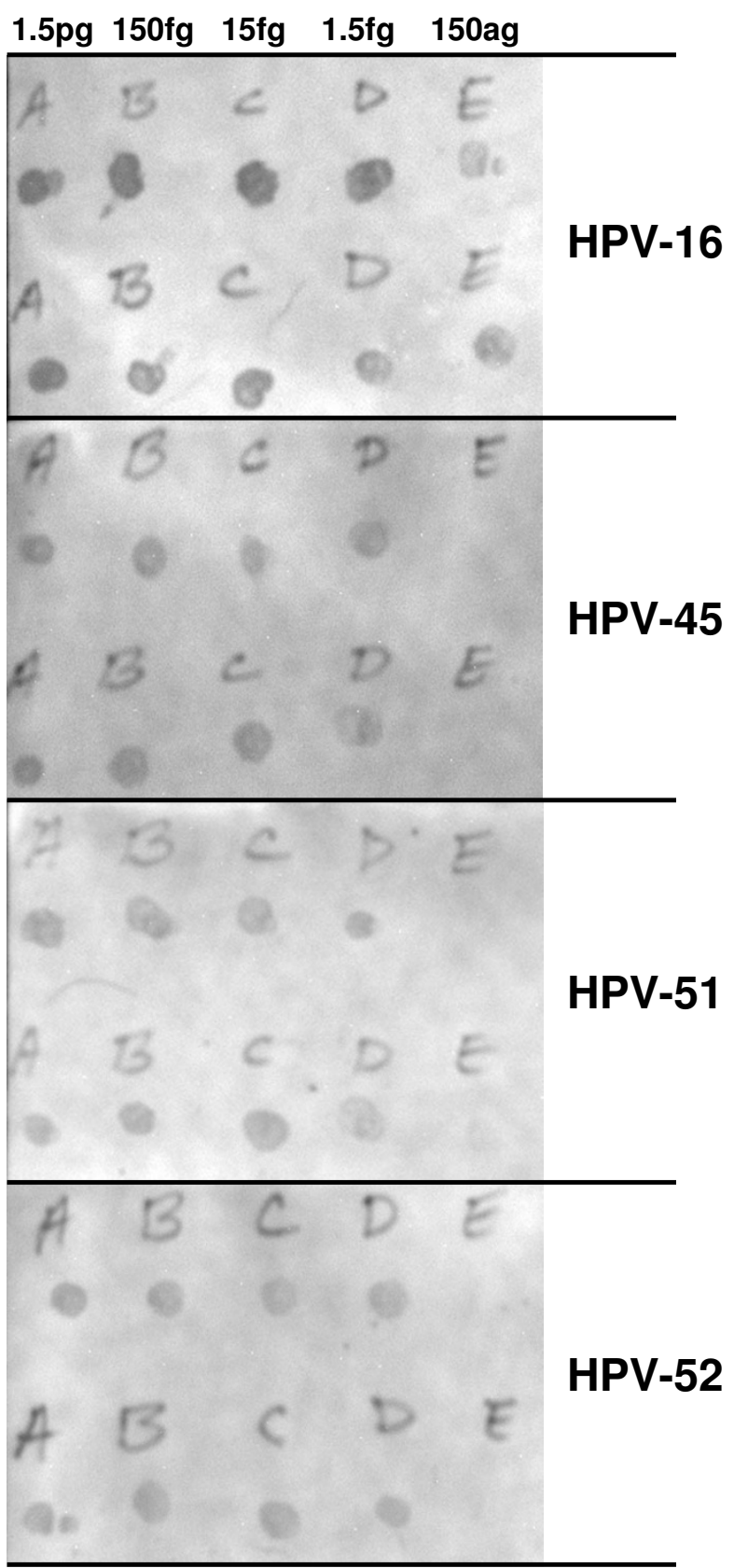

\section{Figure 5}

Dot blot hybridization detection of multiple HPV types after TDP3 PCR. HPV types I6, 45, 5I, and 52 were combined (I.5pg, I50fg, I5fg, I.5fg, or I50ag of each type) in a background of $100 \mathrm{ng}$ C-33A DNA. After PCR, $0.6 \mu \mathrm{l}$ of denatured product was spotted onto nylon membrane and hybridized with biotin-labeled HPV type specific oligonucleotide probe. Duplicate dot preparations were prepared.
HPV types $(6,11,16,18,31,33,35,40,42,52,58,66,67$, 73, 81 [CP8304], 84 [MM8], and cand91 [CP6108]) were detected amongst these 47 samples. Multiple infections were recorded in 9/47 (19\%) samples.

Fifty-four of the 65 'HPV negative' samples were also tested with the MRT protocol. Of these 54 samples, 10 were HPV negative and $44 \mathrm{HPV}$ positive with the TDP3 protocol. Of the 10 negative samples, 1 tested HPV-53 positive by the MRT method, and of the 44 positive samples, $16(36 \%)$ were negative with the MRT method. Five HPV types $(16,18,31,35$, and 81$)$ went undetected by the MRT method in this sample. An additional 25 samples that were negative following primary screening by the TDP3 assay were identified; none tested HPV positive after PCR with the standard GP5+/GP6+ protocol (50 PCR cycles). Two of the 25 samples tested positive (for HPV39, and for HPV-51) by the MRT protocol. Thus, of 44 samples negative with the standard GP5+/GP6+ assay, 44 $(100 \%)$ tested positive with the TDP3 protocol, and 28 (64\%) tested positive with the MRT conditions; and, of 35 samples negative by the standard GP5+/GP6+ assay and the TDP3 assay, $3(8.6 \%)$ tested positive with the MRT protocol.

The TDP3 protocol has subsequently been tested on 799 abnormal cytological samples and $752(94 \%)$ have tested positive for one or other of 37 types: HPV-6, 11, 16, 18, $31,32,33,35,39,40,42,43,44,45,51,52,54,55,56$, $58,59,61,62,66,67,69,70,72,73,81,82,83,84,87$, cand89, cand90, and cand91.

\section{Detection of HPV in FFPE VAIN samples}

The GP5+/GP6+ and TDP3 protocols (both 50 cycles) were compared for the detection of HPV in $5 \mathrm{ng}$, $20 \mathrm{ng}$, 50 ng and 100 ng of DNA extracted from six VAIN lesions (Figure 8). HPV sequences were detectable by TDP3 assay in all six samples at each sample DNA quantity. The GP5+/6+ assay detected HPV in all six cases, but electrophoretic band strength was strong only with 100 ng DNA in the PCR and tended to be weaker or absent at other template DNA quantities (Figure 8). Subsequent analysis (using the TDP3 conditions) of VAIN lesions from 114 patients demonstrated HPV in $111(97.4 \%)$ samples. Twenty-one HPV types were identified: HPV types 6,11 , $16,18,31,33,35,40,42,43,45,51,54,56,58,59,73$, $81,83,84$, and cand90. Double or multiple infections were detected in 19 (13\%) samples.

\section{Detection of HPV in FFPE breast invasive ductal carcinoma samples}

A preliminary assay of 26 IDC samples (arbitrary $10 \mu \mathrm{l}$ of DNA extract) by GP5+/GP6+ PCR demonstrated faint bands upon electrophoresis for five (19\%) samples. Following DNA quantification, one of these samples was 


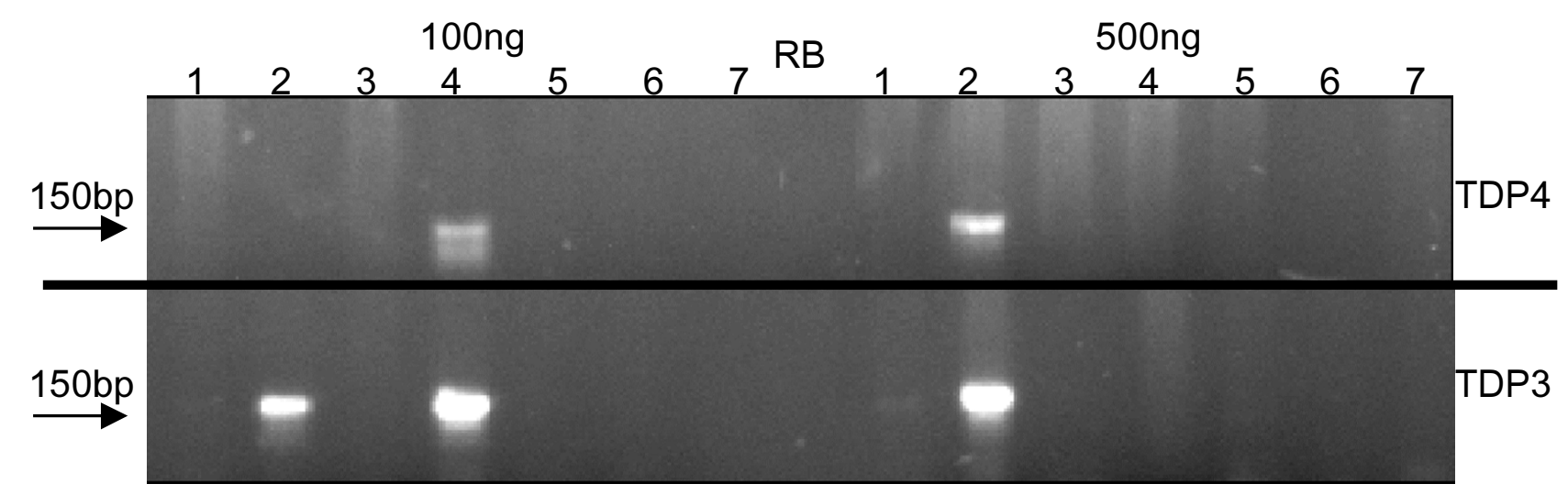

\section{Figure 6}

Amplification of HPV from abnormal cervical cell DNA samples by TDP3 and TDP4. Seven samples that tested negative for HPV using standard GP5+/GP6+ cycling conditions were assessed with the TDP3 and TDP4 assays. Both TDP3 and TDP4 supported the detection of HPV in sample 4 when 100 ng DNA was subject to PCR but not when 500 ng DNA was in a reaction. HPV was detected in sample 2 by the TDP3 protocol with $100 \mathrm{ng}$ or $500 \mathrm{ng}$ template DNA and by the TDP4 protocol at $500 \mathrm{ng}$ but not $100 \mathrm{ng}$ of sample. RB: reagent blank.

compared for detection of HPV by GP5+/GP6+ assay and TDP3 assay (both for 50 cycles), using 20 ng, $100 \mathrm{ng}, 225$ ng, $325 \mathrm{ng}$ or $450 \mathrm{ng}$ of DNA extract in the PCR (Figure 9). A weak band was obtained using the GP5+/GP6+ assay following amplification from $225 \mathrm{ng}$ DNA template but HPV was not detected at any of the other sample concentrations. Bands were clearly visible using the TDP3 assay from $100 \mathrm{ng}, 225 \mathrm{ng}$ and $325 \mathrm{ng}$ sample quantities. There is a faint band after amplification from $20 \mathrm{ng}$, but amplification is not evident for $450 \mathrm{ng}$ sample DNA. The TDP3 assay was subsequently applied to the other 25 breast tumor samples ( 200 ng sample DNA in the PCR) and HPV was detected in another 14 instances (Figure 10). Overall 15/26 (58\%) breast tumors tested positive by this assay for HPV. Dot blot hybridization demonstrated fourteen samples were positive for HPV-16 and one for HPV31.

\section{Discussion}

The main finding of this study is that touchdown general primer PCR coupled with control of the quantity of sample DNA in a PCR supports the detection of low-copy number HPV in an excess background of human DNA sequences. A high percentage of abnormal cervical cytological samples previously recorded as HPV negative tested HPV positive by this approach. It has also been demonstrated that a wide range of HPV types and multiple infections are detectable using a touchdown protocol.

\section{Detection of minority HPV DNA}

The potential of PCR to detect minority nucleic acid species is the genius of the technique. However, the presence of background DNA may compromise PCR efficiency by giving rise to non-specific primer annealing [16]. Assays such as the GP5+/GP6+ use one pair of primers to amplify a wide range of HPV types and necessarily each primer contains varying numbers of mismatches relative to any given HPV type [17]. Low-stringency primer-annealing conditions were originally defined for the GP5+/GP6+ assay [7] however, these conditions permit GP5+/GP6+ primer annealing to human sequences [6].

In this study a hot start step was introduced to prevent annealing that can occur at PCR set-up between primers and single-stranded DNA sequences produced during DNA extraction $[9,16]$. Four touchdown protocols were tested to assess how a touchdown annealing approach affects the amplification of HPV sequences. In the first instance, these protocols were tested on a model system consisting of small quantities of SiHa cell DNA 'hidden' in varying amounts of C-33A cell DNA.

The SiHa cell line is known to contain approximately one slightly truncated copy of the HPV-16 genome integrated in chromosome 13q21-31 [11]. The cell line is hyper-diploid but has been shown to be disomic with respect to chromosome 13 [11]. It is possible to approximate the number of copies of HPV-16 detected by the various protocols tested assuming for the purpose of the approximation that there are $6.6 \times 10^{9}$ DNA base pairs per SiHa cell. One base pair weighs 650 daltons and one dalton weighs $1.66 \times 10^{-24} \mathrm{~g}$. Therefore, one diploid cell contains $7.12 \mathrm{pg}$ of DNA, and there will be one copy of the GP5+/GP6+ primer target per $3.56 \mathrm{pg}$ of SiHa cell DNA extract. It follows that the number of copies of HPV-16 in $0.1 \mathrm{ng}$ of SiHa cell DNA will be 28 ; in $0.5 \mathrm{ng}$ SiHa DNA there will 


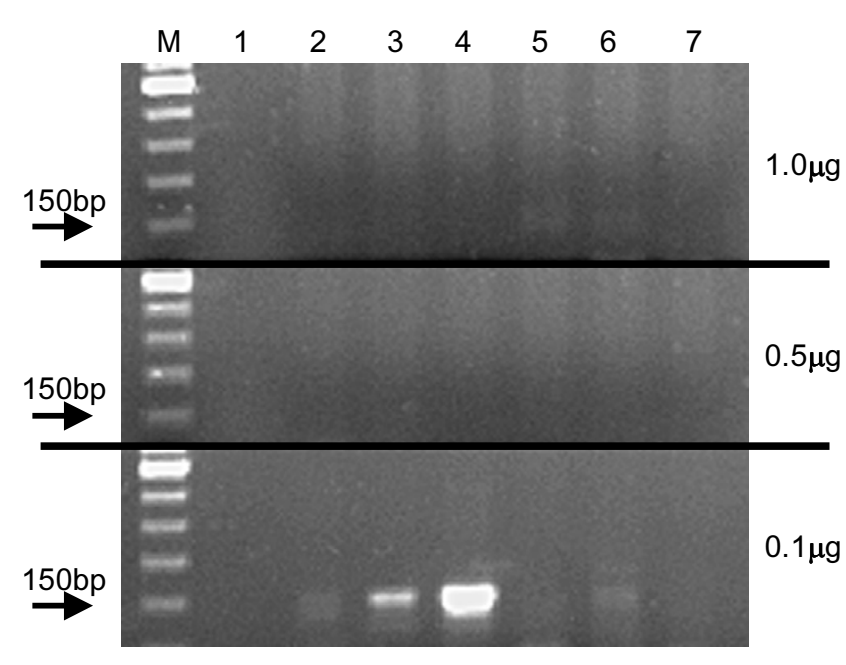

Figure 7

Detection of HPV by TDP3 in abnormal cervical cell samples. Samples had previously tested negative for HPV using standard GP5+/GP6+ cycling conditions. HPV detection was dependent on the total amount of DNA included in the PCR.

be $~ 140$ copies; in $1 \mathrm{ng} \sim 280$ copies; in $25 \mathrm{ng} \sim 7000$ copies and in $100 \mathrm{ng} \sim 28,000$. HPV-16 was amplifiable from smaller quantities of SiHa cell DNA as the total quantity of DNA reduced from $2 \mu \mathrm{g}$ to $500 \mathrm{ng}$ for all protocols. Two touchdown protocols (TDP3, TDP4) were routinely able to detect $0.1 \mathrm{ng}$ SiHa HPV DNA ( 28 copies) in a total DNA quantity of $500 \mathrm{ng}$ (approximately equal to DNA extracted from 70,000 cells [i.e. 1 copy HPV-16 detected per 2500 cells]). In contrast, the best performance of the GP5+/GP6+ protocol was the demonstration of HPV-16 from $1 \mathrm{ng}$ of SiHa cell DNA ( $280 \mathrm{HPV}-16$ copies) in a background of $500 \mathrm{ng}$ total DNA. Unlike TDP3 and TDP4 protocols, the standard GP5+/GP6+ assay failed to demonstrate HPV when the total DNA content in a reaction was $1 \mu \mathrm{g}$ or $2 \mu \mathrm{g}$. It is noticeable from Figure 1 that some of the protocols gave slightly more intense bands, $\sim 150$ bp in size, following amplification of HPV-16 sequences in a background of $500 \mathrm{ng}$ DNA compared to the amplification in a background of $100 \mathrm{ng}$. This empirical finding was reproducible on repeat PCR. This observation is counter-intuitive; however, given the nature of the touchdown approach to annealing, the character of the dilutions, and the high number of PCR cycles, the PCR assays tested are essentially qualitative rather than quantitative.

The significantly improved detection of low-copy HPV-16 by touchdown protocols illustrates the important influence background DNA can have on detection sensitivity. The findings are particular noteworthy given that relative to the target HPV-16 sequence, the GP5+ primer sequence $\left(T_{\mathrm{m}}=45^{\circ} \mathrm{C}\right)$ has just two mismatches and the GP6+ primer $\left(T_{\mathrm{m}}=41^{\circ} \mathrm{C}\right)$ has no mismatches. The data show that under low-stringency annealing conditions and when the target is low-copy HPV, considerable non-specific primer annealing with human sequences must occur despite the near perfect homology of the primers for the HPV-16 L1 open reading frame target.

The MRT GP5+/GP6+ protocol was also found to detect low-copy HPV in a background of human sequences. This assay incorporates periods of slow temperature changes from the denaturation step to the annealing step and from the annealing step to the extension step. This approach may allow for better specific annealing of primers with HPV target during the gradual cooling to the final annealing temperature of $38^{\circ} \mathrm{C}$ than is possible with the standard conditions. Possibly, the express heating/cooling default settings of current generation thermal cyclers may

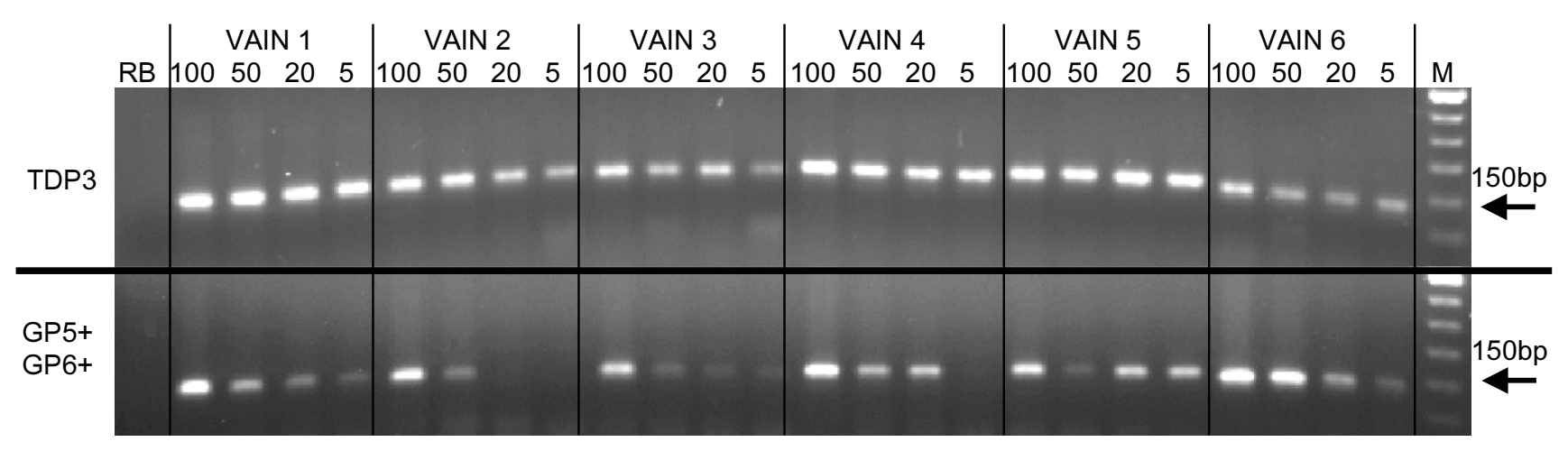

Figure 8

HPV detection in six VAIN lesions by GP5+/GP6+ and TDP3 assays. Sample DNA in PCR: 100 ng, 50 ng, 20 ng, or 5 ng. M: 50 bp molecular weight marker, RB: reagent blank. 


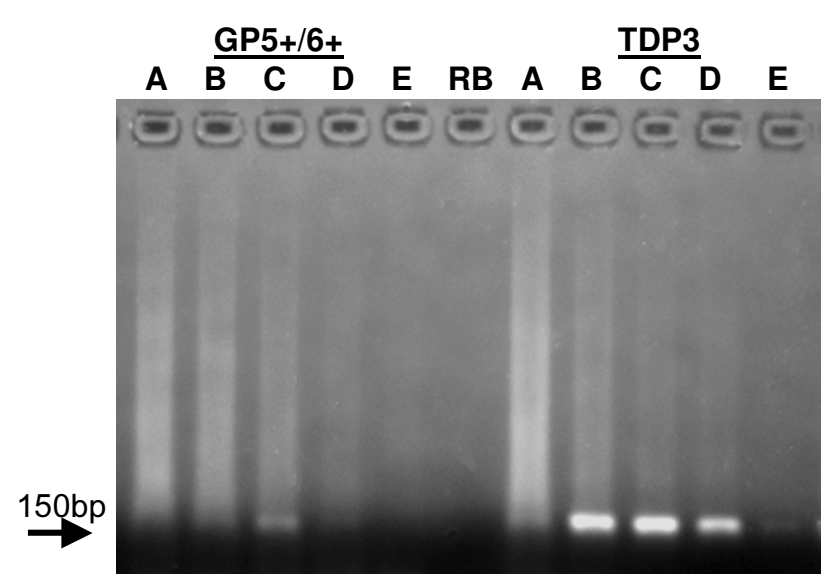

Figure 9

Comparison of GP5+/GP6+ and TDP3 amplification of HPV sequences from a FFPE breast invasive ductal carcinoma. Sample DNA in PCR, A: 450 ng, B: 325 ng, C: 225 ng, D: 100 ng, E: 20 ng. The TDP3 assay facilitated detection of HPV in $100 \mathrm{ng}, 225 \mathrm{ng}$ and $325 \mathrm{ng}$ sample, whereas with GP5+/6+ assay conditions a HPV was detectable (weak band) only when $225 \mathrm{ng}$ sample was in the PCR. 50 cycles of PCR were used with each of the protocols. RB: reagent blank.

compromise the efficiency of the GP5+/GP6+ PCR assay as developed using early generation machines [6,7].

\section{Detection of HPV recombinant plasmid DNA}

To examine the effect of a touchdown protocol on a wider range of HPV types, recombinant HPV/plasmid DNA samples were diluted in C-33A DNA and tested with the TDP3 protocol. There are three primer mismatches with respect to HPV-33, one in the GP5+ primer and two in the GP6+ primer. For HPV-45 there are three mismatches that are all in the GP5+ primer sequence. HPV-31 and 56 each have one mismatch in the GP5+ primer and three in the GP6+ primer. For HPV-52 there are seven mismatches, including five in the GP5+ primer. HPV-51 has the greatest number of mismatches of any HPV type amplified by the GP5+/6+ system: six mismatches in the GP5+ primer and four in the GP6+ primer. Not surprisingly, HPV-16 was the most efficiently amplified type (Figure 3). Amplification product was detectable from 15ag DNA (approximately equivalent to 1 copy of the recombinant HPV plasmid) in a background of $100 \mathrm{ng}$ human DNA (equivalent to 14,000 cells). HPV-45 and 51 were amplifiable from 150ag (10 HPV/plasmid copies); types 33, 52, and 56 from $15 f g$ (100 copies of HPV) DNA; and, HPV-31 from $150 \mathrm{fg}$ (1000 copies) of recombinant DNA. Clearly, for such small quantities of DNA, slight variations in pipetting accuracy and/or DNA concentration estimate might alter the final sensitivity data. Nonetheless, the data indicates firstly that a touchdown protocol can sensitively amplify a range of HPV types, and secondly that the efficiency of amplification may not be a simple function of the number of mismatches between the primer and target sequence. With the TDP3 protocol HPV-31 (4 mismatches) was less efficiently amplified than HPV-56 (4 mismatches), HPV-52 (7 mismatches), or HPV-51 (10 mismatches) (Figure 4, Table 3). The TDP3 amplified six of the seven HPV types tested with greater sensitivity than the standard GP5+/GP6+ conditions. HPV-31 was detectable as a faint band from 15 fg template DNA following the standard PCR, whereas the detection limit with the TDP3 protocol was $150 \mathrm{fg}$ (Figures 3 and 4, Table 3). HPV52 was not detectable by the standard protocol at the dilution range tested but was detectable from $15 \mathrm{fg}$ starting template using the TDP3 protocol. These data again indicate that the detection efficiency for different HPV types by a general primer method may not follow easily predictable rules. General primer annealing involves a dynamic inter-relationship depending on HPV copy number, primer affinity for different HPV types, human sequence concentration, and, primer affinity for human sequences at a given annealing temperature. The empirical data indicate that a touchdown annealing approach helps negotiate these variables to support sensitive detection of a wide range of HPV types.

\section{Detection of multiple HPV types}

This study also examined the ability of a touchdown protocol to amplify HPV types-16 (2 mismatches), 45 (3 mis-

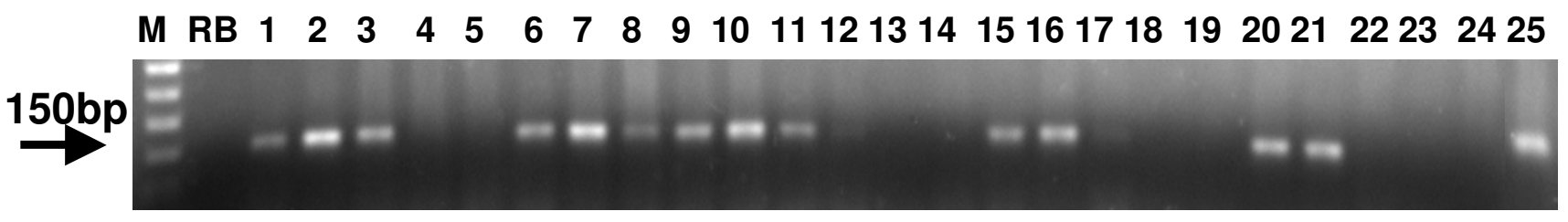

Figure 10

Demonstration of HPV in FFPE breast invasive ductal carcinomas following TDP3 amplification. $200 \mathrm{ng}$ of sample DNA were subject to a total of 50 PCR cycles. Samples I, 2, 3, 6, 7, 8, 9, I0, II, I5, I6, 20, 21 and 25 were recorded as HPV positive following electrophoresis and dot blot hybridization. M: 50 bp molecular weight marker, RB: reagent blank. 
matches), 51 (10 mismatches), and, 52 (7 mismatches) combined in one PCR (Figure 5). Again, HPV-16 was detected with the highest sensitivity; however, the other three types were identifiable following dot blot hybridization demonstrating that the touchdown protocol did not favor HPV-16 amplification to the exclusion of other types. An exhaustive assessment of the effect of different concentrations of HPV types within a PCR on the detection of multiple types was beyond the resources available for this study.

\section{Detection of HPV in cervical smear samples}

An excess of background human DNA is likely to be a common situation when performing PCR on DNA extracted from routine cervical smear samples. The extent to which normal or lesion tissues are scraped from the cervix cannot be controlled. For efficient HPV PCR amplification, the study data strongly support the use of standardized quantities of DNA and not regular volumes containing arbitrary amounts of DNA. Overall, the cell line and clinical sample studies indicate that in a $50 \mu \mathrm{l}$ reaction, between $100 \mathrm{ng}$ and $200 \mathrm{ng}$ sample DNA supports the most efficient PCR. Using optimized amounts of DNA, the TDP3 protocol demonstrated one or other of seventeen different HPV types in 47 of 65 (72\%) abnormal cytology samples HPV negative by the regular GP5+/ GP6+ protocol. Multiple infections were found in 9/47 $(19 \%)$ of the samples.

The MRT GP5+/GP6+ conditions were tested on 54 of the 65 GP5+/GP6+ negative samples. Twenty-eight (64\%) of 44 samples positive by the TDP 3 were also positive by the MRT protocol, and 1 of 10 samples negative by the TDP3 protocol was positive by the MRT. Of an additional 25 abnormal cytological samples negative for HPV by the TDP3 assay, none tested positive with the standard GP5+/ GP6+ method, but two samples were positive by the MRT protocol. Again, these data show that HPV detection can be highly dependent on assay conditions and also demonstrate that two or more methods may be required for inclusive HPV screening. Nevertheless, the above comparison of methods together with the demonstration of HPV in $94 \%$ of 799 abnormal cytological samples indicates a touchdown approach supports wide-ranging and sensitive HPV detection.

\section{Detection of HPV in FFPE samples}

This study also examined the effect of touchdown PCR and sample DNA quantity on the amplification of HPV from FFPE tissues, where DNA quality is likely to be poor. VAIN lesions were chosen as an example of tissues from which HPV virions are actively shed and therefore where HPV DNA is in a relative abundance [18]. Amplification of HPV from VAIN lesions was readily accomplished by both the GP5+/GP6+ and TDP3 protocols although the
TDP3 assay was able to amplify HPV from smaller quantities of template DNA than the GP5+/GP6+ assay (Figure $8)$. The data again illustrates the effect of DNA content on amplification efficiency. Assay of 114 VAIN lesions by TDP3 has demonstrated 21 different HPV types in 111 HPV positive samples, with double or multiple infections in $17(15 \%)$ of the samples, again suggesting that a touchdown approach sensitively detects a wide range of HPV types.

Breast carcinomas were chosen for study as an example of a tumor where there are widely differing estimates of HPV prevalence. Most early studies of breast tumors found no evidence of HPV following PCR assay [5, 19-21]. However, other investigations (by Southern blot hybridization, and by PCR) have reported high-risk HPV types (e.g. HPV-16, 18 , or 33 ) in $24 / 50(48 \%), 5 / 17(30 \%), 19 / 41(46 \%), 14 /$ $32(44 \%)$, and $6 / 17(35 \%)$ breast carcinomas $[4,22-25]$. de Villiers et al. PCR tested paired breast carcinoma and nipple tissues from 29 patients for anogenital and skin HPV types. HPV was detected in 25/29 (86\%) carcinomas and in 20/29 (69\%) nipple tissues [26]. In the present study, application of the GP5+/GP6+ assay using an arbitrary DNA quantity in the PCR indicated 5/26 (19\%) invasive ductal carcinomas were HPV positive. Subsequent assays using the TDP3 protocol and 200 ng of sample indicated 15/26 (58\%) tumors were HPV positive. These data add to the evidence that HPV sequences are present in breast tumor tissues. However, that HPV was detectable in most tumors only after use of a highly optimized PCR protocol may indicate that HPV is in a latent form and/or is confined to a subset of tumor cells or other cells associated with a tumor mass. Perhaps there may be parallels with Epstein Barr Virus (EBV) detection in breast tumors. EBV has been reported in up to $51 \%$ of breast carcinomas by sensitive PCR assay [27], but it has since been suggested the EBV detected is amplified from EBV positive tumor infiltrating lymphocytes and not from tumor cells per se [28]. Further studies are required to determine whether HPV detected in breast tumors represents an incidental 'passenger' or has causal significance. Additionally, given the disparate estimates of HPV prevalence in breast tumors, future studies might incorporate more rigorous control measures such as cutting sections of HPV negative tissues for DNA extraction and PCR in between successive breast tumor specimens to test for cross-contamination with HPV positive samples.

\section{Carry-over contamination control}

In this study dTTP was replaced with dUTP in all protocols in order to identify a sensitive PCR test that also includes a control measure against carry-over contamination. However, uracil N-glycosylase (UNG) is an enzyme that has a degree of thermostability and may also become reactivated after completion of a PCR protocol $[29,30]$. HK ${ }^{\mathrm{TM}}$ - 
UNG (Epicentre) is designed to be heat-labile and free of such shortcomings, but it has been reported that even heat-labile forms of UNG may retain some residual activity and spoil PCR efficiency [29]. Further, dUTP is less efficiently incorporated into PCR amplicons than dTTP [30]. UNG/dUTP usage might therefore result in suboptimal PCR assay performance and even greater sensitivity for HPV might be possible for all the protocols tested using regular dNTPs.

\section{Clinical utility}

The impetus for this study was to determine whether abnormal cytological samples that tested HPV negative by a commonly used PCR assay were in fact HPV positive. Using a touchdown protocol, HPV has been demonstrated in a high percentage of samples previously recorded as HPV negative consistent with HPV representing a necessary cause of most (if not all) abnormal cervical cytological conditions. However, an assay with high analytical sensitivity for HPV might not be appropriate as a clinical test. The HPV status of cytological samples has been proposed as a marker to identify patients with underlying high-grade cervical intraepithelial neoplasia (CIN) [31] and current clinically approved HPV tests detect the bulk of high-grade CIN and invasive cervical carcinoma. Increased sensitivity for HPV might lead to reduced test specificity for high-grade CIN.

\section{Conclusion}

This study has demonstrated that a touchdown modification of the GP5+/GP6+ assay coupled with attention to the quantity of DNA in a PCR significantly improves the detection of low-copy HPV DNA without compromising the ability of the technique to detect a wide range of HPV types or multiple infections. A touchdown approach may be especially beneficial as an analytical test for the re-evaluation of (apparently) HPV negative abnormal cervical cytological or histological samples and for investigating the association of HPV with non-anogenital lesions and tumors. Further studies are required to determine the clinical utility of a touchdown PCR approach to HPV detection and to compare the performance with recently developed (highly sensitive) multi-primer HPV PCR assays such as the PGMY [32] and the $\mathrm{SPF}_{10}$ [33].

\section{Competing interests}

The author(s) declare that they have no competing interests.

\section{Authors' contributions}

MFE conceived and designed the study, performed DNA extractions and PCR assays, and drafted the manuscript. CS-CA carried out DNA extractions, the bulk of the PCR assays, and dot blot and Southern blot hybridization analyses. LS-A performed DNA extractions, PCR, and HPV typ- ing of VAIN tissues. KC contributed to the study conception and design.

\section{Acknowledgements}

The authors are grateful to Sharon L. Mount, M.D. for selecting the vaginal intraepithelial lesions examined, and to Jacalyn L. Papillo, B.S. and Timothy L. St. John, B.S. for the cervical smear samples. This study was supported by a Fletcher Allen Health Care Research and Development Fund Award.

\section{References}

I. Walboomers JM, Jacobs MV, Manos MM, Bosch FX, Kummer JA, Shah KV, Snijders PJ, Peto J, Meijer CJ, Munoz N: Human papillomavirus is a necessary cause of invasive cervical cancer worldwide. J Pathol I999, 189:12-19.

2. Böhmer G, van den Brule AJ, Brummer O, Meijer CL, Petry KU: No confirmed case of human papillomavirus DNA-negative cervical intraepithelial neoplasia grade 3 or invasive primary cancer of the uterine cervix among $5 \mathrm{II}$ patients. Am J Obstet Gynecol 2003, 189: I 18-120.

3. Syriänen K, Syriänen S: HPV infections in other sites and lesions. In Papillomavirus infections in human pathology Ist edition. Edited by: Syrjänen K, Syrjänen S. Chichester: John Wiley and Sons Ltd; 2000:445-458.

4. Kan C-Y, lacopetta BJ, Lawson JS, Whitaker NJ: Identification of human papillomavirus DNA gene sequences in human breast cancer. BrJ Cancer 2005, 93:946-948.

5. Wrede D, Luqmani YA, Coombes RC, Vousden KH: Absence of HPV 16 and 18 DNA in breast cancer. $\mathrm{Br} J$ Cancer 1992, 65:89I-894.

6. Snijders PJ, van den Brule AJ, Schrijnemakers HF, Snow G, Meijer CJ, Walboomers JM: The use of general primers in the polymerase chain reaction permits the detection of a broad spectrum of human papillomavirus genotypes. J Gen Virol 1990, 71:173-181.

7. de Roda Husman AM, Walboomers JM, van den Brule AJ, Meijer C], Snijders PJ: The use of general primers GP5 and GP6 elongated at their $3^{\prime}$ ends with adjacent highly conserved sequences improves human papillomavirus detection by PCR. J Gen Virol 1995, 76:1057-1062.

8. Bauer HM, Greer CE, Manos MM: Determination of genital human papillomavirus infection by consensus polymerase chain reaction amplification. In Diagnostic molecular pathology: a practical approach Volume 2. Ist edition. Edited by: Herrington CS, McGee JO'D. Oxford: Oxford University Press; | $992:|3|-15 \mid$.

9. Chou Q, Russell M, Birch DE, Raymond J, Bloch W: Prevention of pre-PCR mis-priming and primer dimerization improves low-copy-number amplifications. Nucleic Acids Res 1992, 20:1717-1723.

10. Don RH, Cox PT, Wainwright BJ, Baker K, Mattick JS: 'Touchdown' PCR to circumvent spurious priming during gene amplification. Nucleic Acids Res 1991, 19:4008.

II. Meissner JD: Nucleotide sequences and further characterization of human papillomavirus DNA present in the CaSki, SiHa and HeLa cervical carcinoma cell lines. J Gen Virol 1999, 80: 1725-1733.

12. Evans MF, Mount SL, Beatty BG, Cooper K: Biotinyl-tyramidebased in situ hybridization signal patterns distinguish human papillomavirus type and grade of cervical intraepithelial neoplasia. Mod Pathol 2002, I 5:1339-1347.

13. van den Brule AJ, Pol R, Fransen-Daalmeijer N, Schouls LM, Meijer CJ, Snijders PJ: GP5+16+ PCR followed by reverse line blot analysis enables rapid and high-throughput identification of human papillomavirus genotypes. J Clin Microbiol 2002, 40:779-787.

14. de Roda Husman AM, Snijders PJ, Stel HV, van den Brule AJ, Meijer C], Walboomers JM: Processing of long-stored archival cervical smears for human papillomavirus detection by the polymerase chain reaction. Br J Cancer 1995, 72:412-417.

15. Evans MF, Adamson CS, Papillo J, St. John T, Leiman G, Vacek P, Cooper K: An HPV test specific for high-risk types may benefit LSIL management [abstract]. Mod Pathol 2003, 16:64A.

16. Lo YM: Detection of minority nucleic acid populations by PCR. J Pathol 1994, I74:I-6.

17. Jacobs MV, Walboomers JM, Snijders PJ, Voorhorst FJ, Verheijen RH, Fransen-Daalmeijer N, Meijer CJ: Distribution of 37 mucoso- 
tropic HPV types in women with cytologically normal cervical smears: the age-related patterns for high-risk and lowrisk types. Int J Cancer 2000, 87:22I-227.

18. Sugase M, Matsukura T: Distinct manifestations of human papillomaviruses in the vagina. Int J Cancer 1997, 72:4I2-4I5.

19. Bratthauer GL, Tavassoli FA, O'Leary TJ: Etiology of breast carcinoma: no apparent role for papillomavirus types $6 / 1 / 1 / 16 / 18$. Pathol Res Pract 1992, 188:384-386.

20. Gopalkrishna V, Singh UR, Sodhani P, Sharma JK, Hedau ST, Mandal $A K$, Das BC: Absence of human papillomavirus DNA in breast cancer as revealed by polymerase chain reaction. Breast Cancer Res Treat 1996, 39: 197-202.

21. Czerwenka K, Heuss F, Hosmann JW, Manavi M, Lu Y, Jelincic D, Kubista E: Human papillomavirus DNA: a factor in the pathogenesis of mammary Paget's disease? Breast Cancer Res Treat 1996, 41:51-57.

22. Di Lonardo A, Venuti A, Marcante ML: Human papillomavirus in breast cancer. Breast Cancer Res Treat 1992, 21 :95-100.

23. Hennig EM, Suo Z, Thoresen S, Holm R, Kvinnsland S, Nesland JM: Human papillomavirus 16 in breast cancer of women treated for high-grade cervical intraepithelial neoplasia (CIN III). Breast Cancer Res Treat 1999, 53:121-135.

24. Yu Y, Morimoto T, Sasa M, Okazaki K, Harada $Y$, Fujiwara T, Irie $Y$, Takahashi E, Tanigami A, Izumi K: Human papillomavirus type 33 DNA in breast cancer in Chinese. Breast Cancer 2000, 7:33-6.

25. Liu Y, Klimberg VS, Andrews NR, Hicks CR, Peng H, Chiriva-Internati M, Henry-Tillman R, Hermonat PL: Human papillomavirus DNA is present in a subset of unselected breast cancers. J Hum Virol 200I, 4:329-334.

26. de Villiers EM, Sandstrom RE, zur Hausen H, Buck CE: Presence of papillomavirus sequences in condylomatous lesions of the mamillae and in invasive carcinoma of the breast. Breast Cancer Res 2005, 7:RI-II.

27. Bonnet M, Guinebretiere JM, Kremmer E, Grunewald V, Benhamou $\mathrm{E}$, Contesso G, Joab I: Detection of Epstein-Barr virus in invasive breast cancers. J Natl Cancer Inst 1999, 9 1: 1376-1381.

28. McCall SA, Lichy JH, Bijwaard KE, Aguilera NS, Chu WS, Taubenberger JK: Epstein-Barr virus detection in ductal carcinoma of the breast. J Natl Cancer Inst 200I, 93:148-I50.

29. Schmidt M, Frey B, Kaluza K, Sobek H: Application of heat-labile uracil-DNA-glycosylase in improved carryover prevention technique. Biochemica 1996, 2:13-15.

30. Longo MC, Berninger MS, Hartley JL: Use of uracil-DNA-glycosylase to control carry-over contamination in polymerase chain reactions. Gene 1990, 93:125-128.

31. Solomon D, Schiffman M, Tarone R, ALTS Study group: Comparison of three management strategies for patients with atypical squamous cells of undetermined significance: baseline results from a randomized trial. I Natl Cancer Inst 200I, 93:293-299.

32. Gravitt PE, Peyton CL, Alessi TQ, Wheeler CM, Coutlée F, Hildesheim A, Schiffman M, Scott DR, Apple RJ: Improved amplification of genital human papillomaviruses. J Clin Microbiol 2000, 38:357-36I.

33. Kleter B, van Doorn LJ, Schrauwen L, Molijn A, Sastrowijoto S, ter Schegget J, Lindeman J, ter Harmsel B, Quint WGV: Development and clinical evaluation of a highly sensitive PCR-reverse hybridization line probe assay for detection and identification of anogenital human papillomavirus. J Clin Microbiol 1999 , 37:2508-2517.

\section{Pre-publication history}

The pre-publication history for this paper can be accessed here:

http://www.biomedcentral.com/1472-6890/5/10/prepub
Publish with Bio Med Central and every scientist can read your work free of charge

"BioMed Central will be the most significant development for disseminating the results of biomedical research in our lifetime. "

Sir Paul Nurse, Cancer Research UK

Your research papers will be:

- available free of charge to the entire biomedical community

- peer reviewed and published immediately upon acceptance

- cited in PubMed and archived on PubMed Central

- yours - you keep the copyright

Submit your manuscript here:

http://www.biomedcentral.com/info/publishing_adv.asp
BioMedcentral 